\title{
Pengaruh Paket Pupuk Organik, Anorganik dan Pupuk Hayati Terhadap Sifat Tanah dan Hasil Tanaman Kangkung Darat (Ipomea reptana Poir) pada Tanah Vertisol
}

\author{
YAYAN VANDANI, TATI BUDI KUSMIYARTI*), DAN KETUT DHARMA SUSILA \\ Program Studi Agroekoteknologi Fakultas Pertanian Universitas Udayana Jl. PB. Sudirman \\ Denpasar Bali 80231 \\ ${ }^{*}$ E-mail: tatibudi@unud.ac.id
}

\begin{abstract}
The effect of Organic, Inorganic and Biofertilizer Package on the Properties of Soil and Yield of Land Kale on the Vertisol. This study aims to determine the effect of organic, inorganic and biofertilizer packages on the soil properties and yield of land kale (Ipomea reptana Poir) on the Vertisol. The experiment used a Randomized Block Design (RBD) with 6 treatments and 4 replications. Parameters observed consisted of total-N, available-P, available-K, organic-C, cation exchange capacity (CEC), base saturation, $\mathrm{pH}$, permeability, bulk density, total microorganism, plant height, fresh weight of plants and oven dry weight. Statistical analysis using univariate, the effect of treatment seen based on the F test, if the treatment has a significant effect then proceed with the LSD test level of 5\%. The results of variance analysis showed that the effect of the package of organic, inoganic and biofertilizers had a very significant effect on the parameters of organic $\mathrm{C}$, significantly effected the available-P of the soil and did not significantly effect the total-N, $\mathrm{CEC}$, base saturation, $\mathrm{pH}$, permeability, bulk density, total microorganism, and no significant effect on the parameters of land kale.
\end{abstract}

Keywords: Package Organic, Inorganic and Biofertilizer, Properties of soil, Land kale

\section{PENDAHULUAN}

Pemanfaatan tanah Vertisol sebagai lahan pertanian sebagaian besar digunakan untuk tanaman pangan khususnya adalah padi. Penggunaan Vertisol sebagai lahan untuk tanaman hortikultura terbilang kurang. Hal ini dikarenakan Vertisol yang memiliki kendala pada sifat fisiknya yang umumnya teksturnya merupakan liat berat, mempunyai sifat mengembang bila terkena air dan mengkerut bila kekurangan air, kecepatan infiltrasi air yang rendah serta drainase yang lambat (Mukanda dan Mapiki, 2001).

Kangkung merupakan tanaman hortikultura yang masuk ke dalam famili Convolvulaceae. Kangkung dapat tumbuh 
YAYAN VANDANI. et al. Pengaruh Paket Pupuk Organik, Anorganik dan Pupuk Hayati...

baik di dataran tinggi ataupun di dataran rendah. Berdasarkan tempat tumbuh, tanaman kangkung terdiri dari 2 jenis yaitu kankung darat, hidup di tempat yang kering atau tegalan dan kangkung air yang hidup di tempat yang berair dan basah (BPTP, 2009) Kangkung darat (Ipomeae reptana Poir) produktivitasnya di Indonesia cenderung menurun setiap tahunnya. Menurut Kementrian Pertanian (2015) tanaman kangkung yang memiliki luas panen dari tahun 2009 - 2014 cenderung meningkat tetapi hasil produksinya cenderung menurun.

Dalam sistem pertanian monokultur kebiasaan petani menggunakan pupuk kimia (anorganik) dan pestisida sintetis, semakin lama cenderung semakin meningkat. Kegiatan seperti ini bila dilakukan terus menerus dapat menyebabkan terjadinya degradasi pada lahan. Salah satu indikator degradasi lahan adalah menurunnya sifat fisik, kimia dan biologi tanah seperti kandungan bahan organik, unsur - unsur hara tanah, berubahnya lapisan bidang olah menjadi lebih dangkal dan berkurangnya populasi biota tanah.. (Deptan, 2008).

Subak Tegal Lantang merupakan salah satu subak yang menerapkan sistem pertanian monokultur dengan tanaman padi setiap tahunnya. Selain itu penggunaan pupuk anorganik dan pestisida sintetis dilakukan secara terus menerus. Kegiatan tersebut menyebabkan terjadinya degradasi lahan dan penurunan produksi pada Subak Tegal Lantang. Hal ini ditunjukkan dengan hasil analisis tanah awal pada kandungan $\mathrm{C}$ organik tanah yang tergolong dalam kriteria sedang dengan nlai 2,98\%, kandungan $\mathrm{N}$ total tergolong dalam kriteria rendah dengan nilai $0,15 \%$ dan kandungan $\mathrm{K}$-tersedia yang menunjukkan kriteria sedang dengan nilai $0,31 \mathrm{me} / 100 \mathrm{~g}$.

Salah satu usaha untuk mengurangi laju degradasi lahan dan meningkatkan hasil kangkung darat adalah dengan sistem hara terpadu menggunakan kombinasi pupuk organik, anorganik dan juga pupuk hayati. Penelitian Narka (2017) menggunakan kombinasi pupuk organik, pupuk NPK dan pupuk hayati nitrobacter menghasilkan berat tanaman kangkung kering oven 20,39 gram, dibandingkan dengan perlakuan kontrol yaitu sebesar 15,38 gram yang berarti memberikan peningkatan sebesar $32,56 \%$.

Berdasarkan latar belakang masalah di atas, maka penelitian tentang Paket Pupuk Organik, Anorganik dan Pupuk Hayati terhadap Sifat Kimia Tanah dan Hasil Kangkung Darat (Ipomea reptana poir) pada Tanah Vertisol ini penting untuk dilakukan. 


\section{BAHAN DAN METODE}

Penelitian ini terdiri dari 2 tahap yaitu penanaman dan analisis sifat tanah. Penanaman dilaksanakan di Subak Tegal Lantang, Padang Sambian Kelod, Denpasar Barat dan untuk analisis sifat tanah dilakukan di Laboratorium Ilmu Tanah Fakultas Pertanian Universitas Udayana. Penelitian ini dilaksanakan mulai bulan November 2018 hingga bulan Maret 2019.

Alat dan bahan yang digunakan dalam penelitian ini adalah cangkul, sekop, traktor, pisau lapang, ember, plastic $2 \mathrm{~kg}$, alat-alat tulis, penggaris, nampan, alat-alat analisis tanah, oven, timbangan, kertas manila, amplop, gunting, bor tanah, pupuk organik (Putri Amerta Jaya), pupuk anorganik (phonska dan urea), pupuk hayati (Maxigrow) Tanah Vertisol dan pestisida (Diazanon).

Penelitian menggunakan metode experimental dengan Rancangan Acak Kelompok (RAK) terdir dari 6 perlakuan paket pupuk organik, anorganik dan pupuk hayati termasuk kontrol dan masing-masing perlakuan diulang 4 kali sehingga didapatkan 24 petak tanaman.

$\mathrm{P} 0=$ Kontrol (tanpa pupuk)

$\mathrm{P} 1$ = Paket pupuk 5 ton pupuk organik ha ${ }^{-1}+$ $300 \mathrm{~kg}$ phonska ha ${ }^{-1}+200 \mathrm{~kg}$ urea ha ${ }^{-1}$ P2 = Paket pupuk 5 ton pupuk organik ha- ${ }^{-1}+$ $300 \mathrm{~kg}$ phonska ha ${ }^{-1}+200 \mathrm{~kg}$ urea ha- ${ }^{-1}+$ pupuk hayati $1 \mathrm{cc} .1 \mathrm{~L}^{-1}$

P3 = Paket pupuk 10 ton pupuk organik ha ${ }^{-1}$ $+300 \mathrm{~kg}$ phonska ha ${ }^{-1}+200 \mathrm{~kg}$ urea ha ${ }^{-1}$ P4 = Paket pupuk 10 ton pupuk organik ha ${ }^{-1}$ $+300 \mathrm{~kg}$ phonska ha ${ }^{-1}+200 \mathrm{~kg}$ urea ha ${ }^{-1}+$ pupuk hayati $1 \mathrm{cc} .1 \mathrm{~L}^{-1}$ air P5 = pupuk hayati 1cc. $1 \mathrm{~L}^{-1}$

Persiapan lahan meliputi pembersihan lahan dari sisa tanaman, pembajakan dengan traktor, pembutan petakan sesuai dengan jumlah perlakuan dan ulangan. Petakan dibuat dengan luas $2 \mathrm{~m}$ x $3 \mathrm{~m}$ dan jarak antar bedeng $50 \mathrm{~cm}$ dan tinggi petakan $50 \mathrm{~cm}$ (Gambar.1). 
YAYAN VANDANI. et al. Pengaruh Paket Pupuk Organik, Anorganik dan Pupuk Hayati...

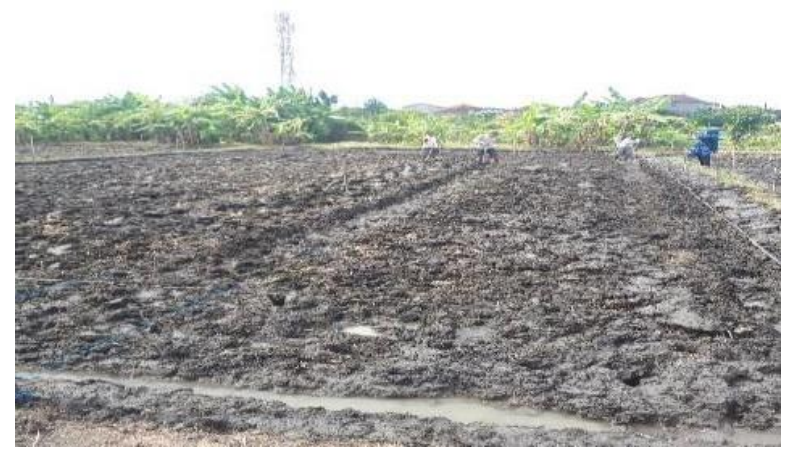

Gambar 1. Persiapan Lahan

Penanaman benih kangkung dilakukan sore hari pada satu minggu setelah pemberian pupuk organik. Benih ditanam dengan jarak tanam $25 \mathrm{~cm} \quad x \quad 25 \mathrm{~cm}$. Penanaman benih kangkung dilakukan dengan cara tugal dengan setiap lubang berisi 4 biji.

Tanaman yang tumbuh dan dipelihara sebanyak 3 tanaman, apabila tanaman tumbuh sebanyak 4 tanaman maka dilakukan penjarangan namun apabila tanaman tumbuh kurang dari 3 tanaman maka dilakukan penyulaman dengan jumlah tanaman yang kurang sehingga menjadi 3 tanaman.

Pemupukan dilakukan sesuai dosis perlakuan dengan menggunakan pupuk organik, pupuk phonska, pupuk urea dan pupuk hayati Maxigrow. Pupuk organik diaplikasikan satu minggu sebelum penanaman benih dengan cara disebar merata di setiap petaknya dengan dosis sesuai perlakuan. Pemberian pupuk phonska dan pupuk urea dilakukan pada umur 10 hari setelah penanaman. Penggunaan pupuk hayati dilakukan sore hari sebanyak 3 kali pada umur 7 hst, 14 hst dan 21 hst sesuai perlakuan dan volume semprot $400 \mathrm{~L}$. ha $^{-1}$.

Pemeliharaan tanaman meliputi penyiraman yang dilakukan pada saat penanaman dan dilakukan penyiraman secara rutin atau dengan menggenangi selokan antar bedengan. Kemudian pembersihan gulma dilakukan saat tanaman berumur muda dan sebelum pemupukan selanjutnya pengendalian OPT dengan menggunakan insektisida Diazinon dengan dosis sebesar $2 \mathrm{cc}$. $\mathrm{L}^{-1}$ air yang disemprotkan pada sore hari.

Pemanenan kangkung darat dilakukan setelah tanaman berumur 35 hari setelah tanam. Pemanenan dilakukan dengan cara mencabut tanaman sampai akarnya 
setiap rumpunnya. Kemudian akar dibersihkan dari sisa tanah yang masih terdapat pada akar (Gambar 2).

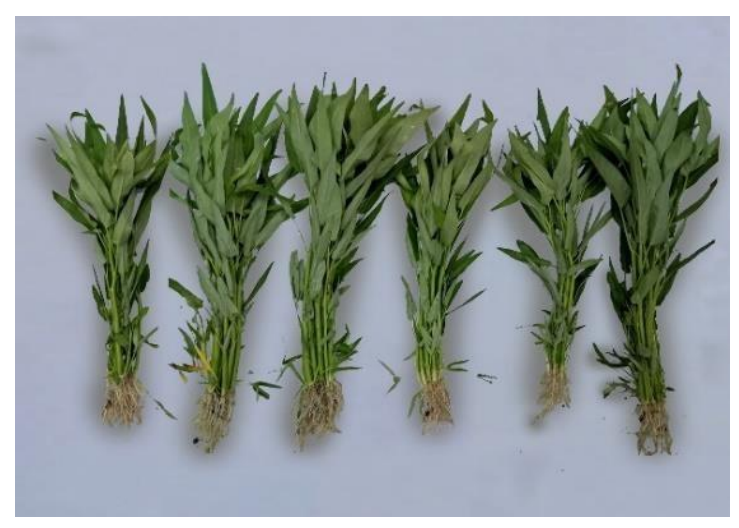

Gambar 2. Hasil Kangkung Darat

Parameter yang diukur meliputi parameter tanah dan tanaman. Parameter Tanah yang diukur adalah $\mathrm{pH}$ tanah, $\mathrm{N}$-total (Kjeldahl), P- tersedia dan $\mathrm{K}$ tersedia (Bray1), C- organik (Wakley and Black), KTK $\left(\mathrm{NH}_{4} \mathrm{OAc}, \mathrm{pH}-7\right), \mathrm{KB}\left(\mathrm{NH}_{4} \mathrm{OAc}, \mathrm{pH}-\right.$

7) Permeabilitas tanah (ring sampel), Berat Volume Tanah (ring sampel), Jumlah Total Mikroorganisme. Parameter tanaman yang diamati meliputi tinggi tanaman, berat segar tanaman dan berat kering oven tanaman.

Data hasil percobaan dianalisis secara univariat sesuai dengan rancangan yang digunakan. Pengaruh perlakuan dilihat berdasarkan uji F, apabila perlakuan berpengaruh nyata terhadap variabel yang diamati, maka dilanjutkan dengan uji beda nyata terkecil (BNT) pada taraf uji 5\%.

\section{Hasil dan Pembahasan}

Hasil analisis statistik untuk mengetahui signifikansi pengaruh pemberian paket pupuk organik, anorganik dan pupuk hayati terhadap sifat tanah dan hasil tanaman kangkung darat disajikan pada Tabel 1. Hasil analisis menunjukkan bahwa pemberian perlakuan paket pupuk organik, anorganik dan pupuk hayati memberikan pengaruh nyata terhadap parameter P-tersedia, berpengaruh sangat nyata terhadap parameter C- organik tanah, tetapi tidak berpengaruh nyata terhadap parameter $\mathrm{N}$ total tanah, K-tersedia tanah, kapasitas tukar kation, kejenuhan basa, keasaman tanah $(\mathrm{pH})$, permeabilitas tanah, berat volume tanah, serta jumlah mikroorganisme tanah. 
YAYAN VANDANI. et al. Pengaruh Paket Pupuk Organik, Anorganik dan Pupuk Hayati...

Demikian juga dengan parameter hasil tidak menunjukkan adanya pengaruh yang tanaman baik tinggi tanaman, berat segar nyata dari perlakuan paket pupuk organik, tanaman dan berat kering oven tanaman anorganik dan pupuk hayati.

Tabel 1. Signifikasni Pengaruh Paket Pupuk Organik, Anorganik dan Pupuk Hayati Terhadap Karakteristik Tanah dan Hasil Tanaman Kangkung Darat

\begin{tabular}{|c|c|c|c|}
\hline No & Parameter Pengamatan & Perlakuan & (P) \\
\hline 1 & N-Total Tanah & ns & \\
\hline 2 & P-tersedia Tanah & $*$ & \\
\hline 3 & K-tersedia Tanah & ns & \\
\hline 4 & C-Organik Tanah & $* *$ & \\
\hline 5 & KTK Tanah & $\mathrm{ns}$ & \\
\hline 6 & KB Tanah & ns & \\
\hline 7 & Keasaman Tanah $(\mathrm{pH})$ & ns & \\
\hline 8 & Permeabilias Tanah & $\mathrm{ns}$ & \\
\hline 9 & Berat Volume Tanah & ns & \\
\hline 10 & Jumlah Total Mikroorganisme & ns & \\
\hline 11 & Tinggi Tanaman & ns & \\
\hline 12 & Berat Segar Tanaman & ns & \\
\hline 13 & Berat Kering Tanaman & ns & \\
\hline
\end{tabular}

Keterangan : $\quad$ ns : Berpengaruh tidak nyata $(\mathrm{P}>0,05)$

* : Berpengaruh nyata $(\mathrm{P}<0,05)$

** : Berpengaruh sangat nyata $(\mathrm{P}<0,01)$

\section{Karakteristik Tanah}

Hasil uji laboratorium terhadap

parameter karakteristik tanah akibat dari perlakuan pemberian paket pupuk organik, anorganik dan pupuk hayati disajikan pada Tabel 2. 
Tabel 2. Hasil Uji Statistik Karakteristik Tanah.

\begin{tabular}{|c|c|c|c|c|c|c|c|c|c|c|}
\hline $\begin{array}{l}\text { Perlaku } \\
\text { an }\end{array}$ & $\begin{array}{l}\mathrm{N}-\mathrm{ttl} \\
(\%)\end{array}$ & $\begin{array}{l}\text { P- tsd } \\
(\mathrm{ppm})\end{array}$ & $\begin{array}{l}\text { K-dd } \\
(\mathrm{me} / \\
100 \mathrm{~g})\end{array}$ & $\begin{array}{l}\text { C-org } \\
(\%)\end{array}$ & $\begin{array}{l}\text { KTK } \\
(\mathrm{me} / \\
100 \mathrm{~g})\end{array}$ & $\begin{array}{l}\mathrm{KB} \\
(\%)\end{array}$ & $\mathrm{pH}$ & $\begin{array}{l}\text { Permea } \\
\text { bilitas (gr/ } \\
\left.\mathrm{cm}^{3}\right)\end{array}$ & $\begin{array}{l}\mathrm{BV} \\
(\mathrm{cm} / \\
\text { jam) }\end{array}$ & $\begin{array}{c}\text { Ttl mikroorga } \\
\text { nisme } 10^{6} \\
(\mathrm{Cfu} / \mathrm{g})\end{array}$ \\
\hline $\begin{array}{l}\text { PO P1 F } \\
\text { P3 P4 } \\
\text { P5 }\end{array}$ & $\begin{array}{l}0,19 \mathrm{a} \\
0,20 \mathrm{a} \\
0,21 \mathrm{a} \\
0,22 \mathrm{a} \\
0,23 \mathrm{a} \\
0,19 \mathrm{a}\end{array}$ & $\begin{array}{l}44,17 \mathrm{a} \\
53,41 \mathrm{~b} \\
45,54 \mathrm{a} \\
53,82 \mathrm{~b} \\
55,61 \mathrm{~b} \\
45,10 \mathrm{a}\end{array}$ & $\begin{array}{l}0,99 \mathrm{a} \\
1,02 \mathrm{a} \\
1,00 \mathrm{a} \\
0,98 \mathrm{a} \\
1,06 \mathrm{a} \\
1,05 \mathrm{a}\end{array}$ & $\begin{array}{l}4,22 \mathrm{~b} \\
3,93 \mathrm{~b} \\
4,52 \mathrm{~b} \\
3,33 \mathrm{a} \\
3,59 \mathrm{a} \\
3,35 \mathrm{a}\end{array}$ & $\begin{array}{l}43,51 \mathrm{a} \\
42,82 \mathrm{a} \\
44,54 \mathrm{a} \\
44,74 \mathrm{a} \\
46,80 \mathrm{a} \\
45,23 \mathrm{a}\end{array}$ & $\begin{array}{l}116,78 \mathrm{a} \\
116,71 \mathrm{a} \\
105,24 \mathrm{a} \\
118,31 \mathrm{a} \\
107,95 \mathrm{a} \\
99,11 \mathrm{a}\end{array}$ & $\begin{array}{l}6,81 \mathrm{a} \\
6,81 \mathrm{a} \\
6,82 \mathrm{a} \\
6,82 \mathrm{a} \\
6,82 \mathrm{a} \\
6,82 \mathrm{a}\end{array}$ & $\begin{array}{l}10,60 \mathrm{a} \\
20,90 \mathrm{a} \\
28,57 \mathrm{a} \\
17,60 \mathrm{a} \\
27,92 \mathrm{a} \\
9,55 \mathrm{a}\end{array}$ & $\begin{array}{l}1,21 \mathrm{a} \\
1,18 \mathrm{a} \\
1,16 \mathrm{a} \\
1,19 \mathrm{a} \\
1,17 \mathrm{a} \\
1,22 \mathrm{a}\end{array}$ & $\begin{array}{l}10,80 \mathrm{a} \\
12,51 \mathrm{a} \\
12,69 \mathrm{a} \\
13,37 \mathrm{a} \\
13,46 \mathrm{a} \\
13,71 \mathrm{a}\end{array}$ \\
\hline $\begin{array}{l}\text { BNT } \\
5 \%\end{array}$ & - & 5,2 & - & 0,4 & - & - & - & - & - & - \\
\hline
\end{tabular}

Penggunaan paket pupuk organik, tanah karena dalam pupuk phonska anorganik dan pupuk hayati berpengaruh mengandung unsur fosfat. nyata pada kandungan $\mathrm{P}$ - tersedia tanah Kandungan C-organik tanah (Tabel 1). Hasil uji lanjut BNT 5\% menunjukkan sangat nyata dipengaruhi oleh menunjukkan pada perlakuan P1, P3 dan P4 penggunaan paket pupuk. Hasil uji lanjut berpengruh nyata dibandingkan kontrol BNT 5\% menunjukkan pada perlakuan (Tabel 2). Hal ini diduga penggunaan pupuk P3, P4 dan P5 berpengaruh nyata organik dapat menghasilkan asam-asam dibandingkan perlakuan P0, P1 dan P2. organik dari dekomposisi lanjut bahan Kandungan C-organik dalam tanah setelah organik. Asam - asam organik yang diberikan perlakuan secara umum dihasilkan dari pupuk organik dapat menunjukkan terjadinya penurunan dari membantu dalam melepaskan jerapan $\mathrm{P}$ oleh pada kontrol tetapi menunjukkan $\mathrm{Ca}$, sehingga kelarutan P-Ca meningkat dan peningkatan dari analisis tanah awal 2,98\%. P menjadi tersedia (Dulur, 2010). Penelitian Penurunan kandungan C-organik akibat Maryati dan Anom (2014) menunjukkan perlakuan diduga karena pupuk organik yang bahwa pemberian kompos dengan dosis 5 diberikan dapat mengalami ton/ha dapat meningkatkan kandungan P- immobilisasi akibat berkembangnya tersedia dari 49,5 ppm menjadi 129,9 ppm. mikroorganisme baik yang ada di dalam Selain itu penggunaan pupuk anorganik tanah maupun akibat penambahan pupuk berupa pupuk phonska dapat membantu hayati. Hal ini dikarenakan bahan organik dalam menyediakan kandungan $\mathrm{P}$ dalam merupakan sumber energi dan sumber $\mathrm{C}$ 
YAYAN VANDANI. et al. Pengaruh Paket Pupuk Organik, Anorganik dan Pupuk Hayati...

bagi perkembangan dan aktivitas anorganik dan pupuk hayati tidak mikroorganisme dalam tanah sehingga berpengaruh nyata pada kandungan $\mathrm{N}$-total kandungan C-organik menurun. Penelian tanah, K-tersedia tanah, KTK, KB, pH tanah, Riyanti, dkk (2015) menunjukkan jumlah total mikroorganisme, permeabilitas penggunaan pupuk organik dengan dosis 5 dan berat volume tanah, meskipun secara ton.ha ${ }^{-1}$ dan pupuk hayati menunjukkan terjadinya penurunan pada kandungan $\mathrm{C}$ organik tanah tetapi jumlah mikroorganisme mengalami peningkatan. Hal ini juga ditunjukkan pada penelitian ini bahwa kandungan jumlah total mikroorganisme secara umum cenderung mengalami peningkatan (Tabel 2).

Peningkatan jumlah total umum menunjukkan kecenderungan peningkatan kandungan hara maupun karakteristik tanah dan hasil tanaman kangkung darat dibandingkan dengan yang tanpa perlakuan/kontrol. Kandungan N-total dan K-tersedia pada perlakuan P4 menunjukkan peningkatan yang paling tinggi jika dibandingkan dengan kontrol, tetapi secara umum P4 tidak berpengaruh mikroorganisme pada perlakuan P1 dan P2 dengan penggunaan pupuk kompos dosis 5 ton/ha dapat meningkatkan kandungan jumlah total mikrorganisme sebesar 12,51 x $10^{6} \mathrm{Cfu} / \mathrm{g}$ dan $12,69 \times 10^{6} \mathrm{Cfu} / \mathrm{g}$ daripada kontrol sebesar 10,80 x $10^{6} \mathrm{Cfu} / \mathrm{g}$. Pada perlakuan P3 dan P4 dengan penambahan dosis pupuk kompos menjadi 10 ton/ha mengalami peningkatan sebesar $13,37 \times 10^{6}$ $\mathrm{Cfu} / \mathrm{g}$ dan $13,46 \times 10^{6} \mathrm{Cfu} / \mathrm{g}$ dari perlakuan P1, P2 dan control. Novita (2013) menyatakan bahwa dengan semakin tinggi kadar bahan organik di dalam tanah maka jumlah total mikroorganisme dalam tanah dapat meningkat selain juga dipengaruhi oleh faktor lingkungan seperti aerasi tanah. nyata dibandingkan P1,P2, P3 dan P5. Hal ini diduga karena dengan penambahan pupuk organik pada dosis 5 sampai 10 ton. ha $^{-1}$ sudah dapat memacu adanya peningkatan kandungan $\mathrm{N}$-total, K-tersedia, dan juga kandungan P-tersedia. Pupuk organik selama proses pengomposan dapat meningkatkan kandungan $\mathrm{N}, \mathrm{P}, \mathrm{K}$ dan unsur hara mikro seperti $\mathrm{Ca}, \mathrm{Mg}, \mathrm{Mn}$ dan $\mathrm{Zn}$ (Kusmiyarti, 2013). Selain itu penggunaan pupuk anorganik berupa pupuk phonska dengan dosis 300 kg.ha- ${ }^{-1}$ dan pupuk urea dengan dosis $200 \mathrm{~kg}$. ha ${ }^{-1}$ dapat membantu dalam meningkatkan kandungan $\mathrm{N}$ dan $\mathrm{K}$ karena dalam pupuk urea mengandung $\mathrm{N}$ sebesar $46 \%$ dan pada phonska mengandung Penggunaan paket pupuk organik, unsur K sebesar 15\% (Lingga, 2000). 
Hasil analisis KTK dan Kejenuhan Basa pada Tabel 2 secara keseluruhan menunjukkan hasil dengan kriteria sangat tinggi (Hardjowigeno, 1993). Peningkatan KTK dan KB disebabkan oleh pemberian pupuk organik (kompos). Hasil dekomposisi lanjut dari bahan organik yang menghasilkan senyawa organik dapat berperan dalam peningkatan koloid organik. Peningkatan jumlah koloid organik akan meningkatkan jumlah muatan negatif dalam tanah sehingga akan meningkatkan nilai KTK. Sedangkan basa-basa hasil minerlaisasi dan pelarutan dari pupuk organik akan terikat dalam jerapan koloid tersebut sehingga kandungan $\mathrm{KB}$ juga sangat tinggi. Jenis mineral liat pada tanah Vertisol umumnya juga meningkatkan nilai KTK dan KB tinggi secara alami. Kandarwati (2016) menyatakan bahwa nilai KTK dan KB tergantung pada jumlah liat dan bahan organik serta komposisi mineraloginya. Semakin banyak jumlah liat dan bahan organik, maka KTK tanah akan meningkat.

Perubahan nilai permeabilitas ditunjukkan pada perlakuan P2 dan P4 yang lebih cepat dibanding kontrol. Meningkatnya kecepatan permeabilitas ini dipengaruhi oleh berat volume tanah, dimana pada perlakuan P2 dan P4 berat volume tanah menunjukkan adanya penurunan. Penurunan nilai berat volume tanah diduga penggunaan paket pupuk organik, anorganik dan pupuk hayati dapat menambah biomassa di dalam tanah yang akhirnya berdampak menurunkan berat volume. Penggunaan pupuk hayati juga dapat mempengaruhi peningkatan aktivitas mikroorganisme sehingga berakibat pada perubahan keadan pori tanah (pori makro dan mikro). Keadaan pori-pori tanah sangat mempengaruhi kecepatan pemeabilitas dan nilai BV tanah. Semakin banyak pori tanah maka permeabilitas akan semakin cepat dan berat volume akan lebih rendah. Hal ini sejalan dengan Sartohadi (2012) yang menyatakan bahwa permeabilitas dapat dipengaruhi oleh keadaan atau ketersediaan pori tanah. Sudaryono (2001) juga mengatakan bahwa peningkatan permeabilitas tanah disebabkan oleh menurunnya berat volume tanah.

\section{Hasil Tanaman Kangkung Darat}

Perlakuan paket pupuk organik, anorganik dan pupuk hayati memberikan pengaruh terhadap hasil rata-rata tinggi tanaman, berat segar tanaman dan berat kering oven tanaman. Parameter tinggi tanaman tertinggi diperoleh pada perlakuan P1 yaitu sebesar 51,16 cm lebih tinggi dari P0 sebesar 46,16 cm. Pada parameter berat segar tanaman dan berat kering oven 
YAYAN VANDANI. et al. Pengaruh Paket Pupuk Organik, Anorganik dan Pupuk Hayati...

tanaman tertinggi diperoleh pada perlakuan sebesar 75,30 g dan 28,11 g. (Tabel 3).

P3 yaitu masing-masing sebsar 94,70 $\mathrm{g}$ dan

34,54 g lebih tinggi dari P0 masing-masing

Tabel 3. Hasil Pengukuran dan Analisis Statistik Hasil Tanaman Kangkung Darat

\begin{tabular}{|c|c|c|c|}
\hline Perlakuan & $\begin{array}{l}\text { Tinggi Tanaman. } \\
\operatorname{Petak}^{-1}(\mathrm{~cm})\end{array}$ & $\begin{array}{c}\text { Berat Segar } \\
\text { Tanaman. Petak }{ }^{-1} \\
(\mathrm{~g})\end{array}$ & $\begin{array}{cc}\text { Berat Oven } & \text { Berat segar } \\
\text { Tanaman. }^{-1} \text { petak }^{-1}(\mathrm{~g}) \text { tanamana. }^{-1} \text { (ton) }\end{array}$ \\
\hline
\end{tabular}

(g)

\begin{tabular}{ccccc}
\hline P0 P1 P2 P3 P4 & $46,16 \mathrm{a}$ & $75,30 \mathrm{a}$ & $28,11 \mathrm{a}$ & $12,05 \mathrm{a}$ \\
P5 & $51,16 \mathrm{a}$ & $84,30 \mathrm{a}$ & $29,54 \mathrm{a}$ & $13,49 \mathrm{a}$ \\
& $48,53 \mathrm{a}$ & $79,50 \mathrm{a}$ & $24,19 \mathrm{a}$ & $12,72 \mathrm{a}$ \\
& $48,96 \mathrm{a}$ & $94,70 \mathrm{a}$ & $34,54 \mathrm{a}$ & $15,15 \mathrm{a}$ \\
& $46,82 \mathrm{a}$ & $83,00 \mathrm{a}$ & $31,86 \mathrm{a}$ & $13,28 \mathrm{a}$ \\
& $42,82 \mathrm{a}$ & $59,25 \mathrm{a}$ & $17,54 \mathrm{a}$ & $9,48 \mathrm{a}$ \\
\hline
\end{tabular}

BNT 5\%

Tanaman kangkung darat merupakan tanaman sayuran yang dimanfaatkan daunnya sehingga tanaman ini dominan memerlukan unsur hara $\mathrm{N}$ dalam jumlah yang tinggi untuk pertumbuhannya. Laju pertumbuhan tanaman sangat dipengaruhi oleh ketersediaan unsur hara di dalam tanah selain kemampuan tanaman dalam menyerap unsur hara. Kurang optimalnya pertumbuhan tanaman karena ketersediaan unsur hara yang rendah menyebabkan proses pertumbuhan tanaman terhambat. Dalam hal ini unsur hara $\mathrm{N}$ sangat diperlukan dalam pertumbuhan tanaman. Latarang dan Syakur (2006) menyatakan bahwa unsur hara $\mathrm{N}$ merupakan komponen penyusun dari banyak senyawa essensial bagi pertumbuhan tanaman, yang terkandung dalam klorofil. Dalam penelitian ini kandungan unsur hara $\mathrm{N}$ berkisar antara $0,19 \%-0,23 \%$ (Tabel

2) yang termasuk dalam kriteria rendah sampai sedang. Dengan kandungan $\mathrm{N}$ sebesar $0,19 \%-0,23 \%$ diduga belum mampu memberikan perbedaan hasil yang signifikan, tetapi secara umum hasil tanaman kangkung darat cenderung mengalami peningkatan hasil dibandingkan dengan kontrol (P0).

Peningkatan tertinggi hasil tanaman kangkung darat ditunjukkan pada perlakuan 
P3 dengan nilai 15,15 ton.ha ${ }^{-1}$ dari pada kontrol dengan nilai 12,05 ton. ha ${ }^{-1}$ (Tabel 3). Penggunaan paket pupuk organik dan anorganik saja pada perlakuan P3 tidak menunjukkan perbedaan yang nyata dibandingkan dengan perlakuan P4 pada hasil karakteristik tanah (Tabel 3), sehingga penggunaan paket pupuk P3 dengan dosis 10 ton pupuk organik. ha- ${ }^{-1}, 300 \mathrm{~kg}$ phonska. ha 1, $200 \mathrm{~kg}$ urea. ha ${ }^{-1}$ dapat meningkatkan hasil tanaman kangkung darat. Penggunaan paket pupuk dengan penambahan pupuk hayati dalam perlakuan justru menunjukkan adanya penurunan hasil tanaman kangkung darat dibandingkan paket perlakuan yang tidak ditambahkan pupuk hayati.

\section{SIMPULAN}

Berdasarkan hasil penelitian dan pembahasan yang diuraikan maka didapatkan simpulan sebagai yaitu perlakuan paket pupuk P3 dan P4 memberikan pengaruh yang sama baiknya terhadap sifat tanah pada lokasi penelitian. Perlakuan paket pupuk P3 memberikan pengaruh yang terbaik terhdap peningkatan hasil kangkung darat.

\section{DAFTAR PUSTAKA}

Balai Pengkajian Teknologi Pangan (BPTP). (2009). Budidaya Kombinasi Bahan
Baku Limbah Organik. Jurnal Agrotrop, 3(1):83-82(2013) Kangkung Darat Semi Organik. Balai Besar Pengkajian dan Pengembangan Teknologi Pertanian Departemen Pertanian Jambi. Jambi

Departemen Pertanian. (2008). Pedoman Tehnik Reklamasi lahan Sawah Berbahan Organik Rendah Tahun 2008. Direktorat Pengelolaan lahan. Direktorat Pengelolaan Lahan dan Air. Jakarta.

Dulur, Ni Wayan D. (2010). Kajian Bahan Organik dan Bakteri Pelarut Fosfat Terhadap di Tanah Vertisol. Jurnal Agroeksos (20) 2-3. Hlmn 119-123.

Hardjowigeno. (1993). Klasifikasi Tanah dan Pedogenensis. Penerbit Akademi Pessindo. Jakarta

Kementrian Pertanian. (2015). Statistik Produksi Hortikultura Tahun 2014. Dirokterat Jenderal Hortikultura Kementrian Pertanian. Jakarta. Halaman 72.

Kusmiyarti, Tati B. (2013). Kualitas Kompos dari Berbagai Kombinasi Bahan Baku Limbah Organik. Jurnal Agrotrop, 3(1):83-82(2013)

Latang dan Syakur. (2006). Pengaruh Pemberian Bahan Organik Terhadap Pertumbuhan dan Produksi Bawang Merah. Jurnal Hortikultura.5(5):3943.

Lingga, P dan Masson. (2000). petunjuk Penggunaan Pupuk. Penebar Swadaa. Jakarta. Jurnal Ilmu Tanah Volume 7. No 2. Hlmn 12-19

Maryati., Nelvia., Anom E. (2014). Perubahan Kimia Tanah Sawah Saat Serapan Hara Maksimum Oleh Padi (Oryza sativa L.) setelah Aplikasi Campuran Kompos Tandan Kosong Kelapa Sawit (TKKS) dengan Abu Boiler. JomFaperta.1(1)

Mukanda, N. and A. Mapiki. (2001). Vertisols Management in Zambia. $p$. 
YAYAN VANDANI. et al. Pengaruh Paket Pupuk Organik, Anorganik dan Pupuk Hayati...

129-127. Dalam Prasetyo, B. H. 2007. Perbedaan Sifat-Sifat Tanah Vertisol dari Berbagai Bahan Induk. Jurnal Ilmu- Ilmu Pertanian Inodnesia. Volu,e 9, No. 1, 2007, hlm,20- 31.

Narka, I Wayan. (2017). Pengaruh Residu Pemberian Pupuk Organik, Anorganik dan Pupuk Hayati Terhadap Pertumbuhan Tanamn Kangkung (Ipomea reptana Poir). Fakultas Pertanian Universitas Udayana. Bali.

Novita, D. (2013). Pengaruh Pupuk Terhadap Sifat Kimia Tanah dan Populasi Mikrob Rzosfer Tanaman Kilemo (Litsea cubeba Pers). Institut Pertanian Bogor. Bogor.

Riyanti, shoni., Heni P., Sugiyanta (2015). Pengaruh Aplikasi Pupuk Organik dan Pupuk Hayati Serta Reduksi Pupuk NPK terhadap Ketersediaan Hara dan Populasi Mikroba

Tanah pada Tanaman Padi Sawah Musim Tanam Kedua di Karawang, Jawa Barat. Jurnal Agrohorti 3(3) : 330-339 (2015).

Sartohadi, Junun, dkk. (2012). Pengantar Geografi Tanah. Yogyakarta: Pustaka Belajar.

Sudaryono. (2001). Pengaruh Pemberian Bahan Pengkondisi Tanah terhadap Sifat Fisik dan Kimia Tanah pada Lahan Marginal Berpasir. Jurnal Teknologi Lingkungan, (online), Vol.2 No.1:106112 ,

(http://ejurnal.bppt.go.id/index.php/JTL/ar ticle/download/220/166), diakses tanggal 20 Maret 2015. 